\title{
Disturbing Innocence: Defamiliarizing Narco Violence through Child Protagonists in Fiesta en la madriguera and Prayers for the Stolen
}

Este artículo elabora un marco teórico benjaminiano para mostrar la manera en que las novelas Fiesta en la madriguera, de Juan Pablo Villalobos, $y$ Prayers for the Stolen, de Jennifer Clement, manejan la frecuentemente insólita percepción de los niños para desestabilizar los modos habituales de pensar el cuerpo, las drogas y la violencia. Tochtli, hijo de un capo, y Ladydi, una muchacha pobre de Guerrero, crean visiones desorientadoras que constituyen una especie de intoxicación que expone otra: la exaltación del yo soberano y autónomo que acompaña actividades ostensiblemente distintas como hacer compras, el abuso de la cocaína y el narcotráfico.

Palabras clave: Narcotráfico, violencia, intoxicación, niños, consumismo

This article uses a Benjaminian framework to show how the two novels studied, Fiesta en la madriguera, by Juan Pablo Villalobos, and Prayers for the Stolen, by Jennifer Clement, leverage children's unorthodox ways of perceiving the world in order to upend habitual ways of thinking about drugs and drug violence. Tochtli, a capo's son, and Ladydi, a poor girl from Guerrero, create disorienting visions that constitute one mode of intoxication that exposes another: the exaltation of the sovereign and autonomous self that accompanies apparently disparate activities like shopping, cocaine abuse, and drug trafficking.

Keywords: Drug trafficking, violence, intoxication, children, consumerism

A generation's experience of youth has much in common with the experience of dreams. Its historical configuration

is a dream configuration. Every epoch has such a side

REVISTA CANADIENSE DE ESTUDIOS HISPÁNICOS 43.2 (INVIERNO 2OI9) 
turned toward dreams, the child's side.

- Walter Benjamin

In Luis Buñuel's classic 1974 film, Le Fantôme de la liberté, one of the loosely connected vignettes centers on a young girl who is said to have disappeared without a trace from school. The parents first question the school authorities and then take up the matter with the police. All in all, it is a rather subdued portrayal of a presumably traumatic event, other than the odd fact that the girl is present throughout, first at the school, then at the police station as they fill out the missing person report. When young Aliette points out her presence to her mother as the headmistress explains her disappearance, she is reprimanded for interrupting the school official. At the police station, she is again brusquely silenced by the commissioner, although he then enlists her help to fill out the report for her own disappearance.

In their inability to see Aliette and their refusal to hear her, three central disciplinary social institutions - the family, the school, and the police - are seen to constitute the child as a radical Other that is denied subjectivity and agency, being necessarily and exclusively the object of rational adulthood and the raw material out of which it replicates itself. A child's truth, if it is at odds with truth of adult authority, must be rejected as pertaining to an alien and unknown epistemology. Aliette herself, on the other hand, recognizing her own presence and the absurdity of the situation, fulfils the role of the child in the story of the emperor's new clothes, the only one to recognize or admit the obvious. This discrepancy between adult and child perception comes to the forefront in two striking Mexican novels that deal with drug trafficking and the associated violence, Fiesta en la madriguera and Prayers for the Stolen. It falls upon Jennifer Clement's Ladydi and Juan Pablo Villalobos's Tochtli to narrate a phenomenon known for defying representation, and through the authors' remarkable aesthetic evocation of childhood consciousness, the reader comes away with a decentered view of the world capable of disrupting habitual patterns of thought about drugs and drug violence.

According to sociologist Chris Jenks, children's words are commonly "viewed with suspicion, or indifference," since the dominant Piagetian model of development considers the childish or childlike in children to be simply a chaotic background noise against which adult reason gradually asserts itself (135). Childhood is constructed as an implacable process of integration into "the consensus that comprises the tyrannical realm of fact" (Jenks 25). In the words of Susan Buck-Morss, "Piaget was content enough to see childhood thinking disappear. The values in his epistemological system were tipped toward the adult end of the spectrum" (Buck-Morss, The 
Dialectics 263). Walter Benjamin, on the other hand, was more interested in "what was lost along the way," and considered "the repression of childhood and its cognitive modes... a problem of the utmost political significance" (Buck-Morss, The Dialectics 263). For Benjamin, children possessed an ability to unify perception and action in a spontaneous, improvised appropriation of the objects they inherit from the adult world. Educational institutions, normally seen as supporting children's development as they leave behind their outmoded, childish ways of thinking, were considered to suppress a creative faculty that Benjamin related to revolutionary consciousness in adults (263).

Whereas adults practice established modes of constructing reality, children, fascinated by these processes, fixate upon their detritus and put it to improvised use. "In waste products they recognize the face that the world of things turns directly and solely to them. In using these things, they do not so much imitate the works of adults as bring together, in the artifact produced in play, materials of widely differing kinds in a new, intuitive relationship" (Benjamin, One-Way Street 3I). In this sense, children possess a faculty that is anti-habitual and defamiliarizing; their ways of seeing seem intoxicated or intoxicating from an adult perspective. They do not discriminate as rigidly as adults between concrete reality and dreams or fantasy, ${ }^{,}$and this engagement with dream-consciousness or primary processes makes children privileged stewards of a cognitive mode that was highly prized by Benjamin for its political potential (Buck-Morss, The Dialectics 262).

Psychologist Danielle Knafo notes that in young children, "knowing and feeling are not yet differentiated, and even inanimate objects are experienced as vital and alive," invoking the notion of a syncretistic, "undifferentiated perception ... in which an object is perceived in all its forms" ("The Senses" 577). Such perception, brought back into the light of adult analytical thought, is perhaps the basis of Benjamin's dialectical image, which draws "dream images into an awakened state" in that they are then understood in the light of historical knowledge (Buck-Morss, The Dialectics 26I). Thus, while artists may turn to drugs, as Knafo reports, to circumvent habituated adult mentation and "uncover buried - childlike - aspects of the mind ("The Senses" 580), this shows that it is, in fact, childhood consciousness that serves as the model and source of inspiration for such unbound, spontaneous cognition. ${ }^{2}$ The connection between childhood, dreams, drugs, and art is elegantly condensed in a drawing Benjamin made under the influence of mescaline, in which the German words for "sheep" and "sleep" wind around to form the shape of an embryo (On Hashish 9I). The lens of drug-colored creative expression reveals the hidden collusion between dreams and the animal non-rationality of beings innocent of adult 
habits and able to undermine them through a profound fluidity of association. This subversive ability is what allows children (or child-like cognition) to shatter the rigid structures that constitute addictions of thought and emotion through which adults have learned to relate to themselves and their world.

In this sense, one intoxication is arrayed against another, as a hallucinatory optic destabilizes widespread patterns of narcossism, a dynamic in which mind-altering substances and practices are integrated into the self in order to support an inflated ego at the expense of relationships with the Other. 3 Narcossism leverages the closed, atomistic Western self that Benjamin saw underwriting bourgeois culture and fortifies it to withstand the intense social competition and ethical isolation of contemporary consumer capitalism.4 Indeed, licit consumption is the everyday means by which "the self is pumped up ... by a chemical prosthesis" (Ronell, "Interview"), albeit an endogenous one. Work in neuroeconomics has shown that the mere sight of status goods can trigger the release of dopamine in the brain's reward circuitry (Erk passim), pointing to the psychotropic construction of contemporary selves in competition with - and to the exclusion of - the Other, whether the consumer's peers or the distant producers of the goods consumed. 5

These exclusionary dynamics are by no means limited to licit consumerism; psychological research shows that cocaine produces feelings of dominance and autonomy, obviating any dependence on others (Spotts and Shontz I3I). In a strangely complementary way, however, the purity discourses of the Drug War also involve an intoxicating reification of inflated individual and collective selves (Patteson 242), as the global North blames its problems with illicit pharmaka "on the South as a region of contamination and multiple threats" (Herlinghaus 52). Both phenomena thus "share a basis in a narcossistic negation of the Other, whether personal, racial or national" (Patteson 243). ${ }^{6}$ What is more, as consumerist culture spreads across the globe, marginalized communities feel acutely the disjunction between the projected model of contemporary identity formation and their ability to participate in it. Some individuals predictably resort to violence as "una herramienta para cumplir con las exigencias de la sociedad hiperconsumista y sus procesos de subjetivación capitalista" (Valencia 192). Fiesta en la madriguera and Prayers for the Stolen dramatize how people that have enriched themselves through drug trafficking often display levels of narcossism that would make Wolf of Wall Street's Jordan Belfort blush, constructing inflated selves not only through economic and chemical inputs but also through the psychotropy of violence and dominance.7 
The child narrators in the novels analyzed in this study are not reverently presented as the bearers of a transcendent truth, but rather their ways of thinking and being are appropriated for their corrosive (toxic) effect on addictive, narcossist patterns of thinking the self. In fact, the intergenerational transmission of knowledge and values is foregrounded in both novels, and while both child narrators are profoundly influenced by their parents, their improvised use or understanding of these inherited concepts casts them in a harsh new light. Tochtli is the spoiled and eccentric young son of a Mexican capo who lives in an opulent palace that effectively becomes his prison because of security concerns. Violent death is clearly a fact of life for him, and he readily develops systems to classify and enumerate this violence according to the norms of rational thought. But much like Borges's famous inventory of types of animals supposedly found in "cierta enciclopedia china," Tochtli's bizarre systems of classification only throw our habitual ones into relief, exposing the fact that "no hay clasificación del universo que no sea arbitraria y conjetural" (Borges I42-43). By way of an ill-fated safari to Africa and its aftermath, Fiesta en la madriguera explores the process by which Tochtli's exuberance is whittled away as he is socialized into the extreme narcossism embodied by his father. Prayers for the Stolen relates the story of Ladydi, a young girl from Guerrero whose life is upended when her friend Paula is kidnapped by narcos to be a sex slave. Ladydi, who is later wrongly imprisoned for murder, places her unusual and intuitive perception at the service of an ingenuous belief in human goodness and connection, casually calling into question common habits of thought and emotion surrounding drug violence.

CONSUMING INFORMATION, CONSUMING LIFE

Tochtli and Ladydi have much to say about consumption, whether of living creatures, luxury goods, drugs, or information, and their ways of understanding such consumption are notable for their capacity to unsettle and illuminate. The way they tell it, the distinction between human and animal often becomes blurred, and the human body, often constructed in adult discourse as a closed, finished, autonomous container of the self, suffers peculiar disintegrations, multiplications, fusions, and inversions. While such corporeal instability could be understood as merely a symptom of our child narrators' exposure to extreme violence, these disturbing visions of amorphous human bodies defamiliarize life, death, and the body itself as they join other living creatures, inanimate objects, and flows of information as products to be bought, sold, and traded, physically devoured and excreted, or simply used up and thrown away. ${ }^{8}$

Some of the mainstream consumer behavior portrayed appears troublingly mundane when carried out by murderous drug traffickers. 
Villalobos studied and worked in marketing prior to having, like Tochtli's tutor, Mazatzin, a "crisis vocacional" that saw him dedicate himself to fiction (Fermín).9 This inside perspective no doubt helped inform the (hyperbolic) treatment of economic consumption that allows the novel to foreground the suppression of childhood consciousness in the formation of a psychosocial dynamic whose excess and violence parody the psychotropy of mainstream consumer culture and the relentlessness of neoliberal capitalism. For example, Tochtli and his father Yolcaut go on an African safari to capture some new pets (endangered Liberian pygmy hippopotami), in a symbolic reenactment of colonialism that cements the capo's place as a usurper of the heritage of global capitalism, at odds with the established rules of the game but faithful to its spirit of unlimited profit and ruthlessness. However, when Villalobos focuses on details like Yolcaut's habit of buying Tochtli turtles and hamsters to appease him or on their other vacations (Tochtli compares Monrovia unfavorably to Orlando), their behavior is brought into pointed comparison with the more mundane consumerist habits of the global middle class.

Tochtli's narcossist training in fact begins with his father showering him with gifts to make up for the yawning gaps in his emotional life. The hats he is obsessed with serve the purpose of "distinción," as Tochtli so eloquently puts it. Without a hat to make you stand out, "terminas siendo un don nadie" (Villalobos, Fiesta I2). In this sense, these consumer products are a guarantor of personhood, which for Tochtli is at risk of being cancelled by a lack of the appropriate attire or by a violent death - "los muertos no son personas, los muertos son cadáveres" (20). But his hats also fill in for the friends he is not allowed to have; wearing them, he transforms himself into new personalities to simulate the social interaction that is denied him (6r). Here, Tochtli's childlike thinking resists the isolation into which he is being (anti)socialized, but already this is only possible by means of a psychotropic construction of the self through the acquisition of consumer goods. When Yolcaut's cook and his maid bring two boys to the palace to play with Tochtli, he is impeded from connecting to them by a sense of superiority, and he is unable to accept the simple gifts they bring him (86-87). Accepting the generosity of others undermines the self's autonomy and so is intolerable to the budding narcossist. Tochtli's father's gifts to him, on the other hand, are a transaction, a payment for the deprivations Tochtli suffers, and a parenting method by which Yolcaut presents material consumption as the best way to overcome any difficulty (85).

Tochtli's persistent stomachaches are another indicator of the fundamental lack that he must learn to bear "como los machos" (Villalobos, Fiesta 47, 13). After their doctor suggests that this chronic problem is a psychosomatic response to Tochtli's distress at his mother's absence, he is 
never called to the house again (48).10 But the symptom flares up when Tochtli is unable to fulfill his consumer desires (I4), from which it may be surmised that his desire for his mother is displaced onto these products. Thus, when they are denied him, the original lack makes itself felt in the stomach pains, which he describes as "un vacío que va creciendo y creciendo" (47). Put another way, Tochtli's sense of self is structured through an addiction to consumer goods that stands in for a relationship with his mother, in a psychic structure that temporarily accommodates both his residual childish creativity and desire for sociality (as he actually imagines himself transforming upon donning a new hat), and his budding patterns of narcossism. His hats and other possessions, to quote Ronell, are "invested as an ideal object - something that you want to incorporate as part of you," and when his "drug" is unavailable, this "precipitates a major narcissistic crisis" ("Interview"). In this way, he may not be entirely different from those "privileged" children whose parents work constantly to maintain a high level of consumer comfort and prestige that must then supplement their absence from the lives of their children. The tension between Tochtli's whimsicality and desire for companionship on one hand and his training as a domineering macho moves definitively toward a resolution with the conclusion of the incident involving his hippopotami. We will return to this moment in the next section, which explores in more depth the relationship between childish perception and adult "wisdom."

First, we must turn to the consumption of the human body, which, in both novels, suffers a radical demotion in ecological terms, as it becomes actual or potential food for other organisms. There is no more fundamental, vital vulnerability than the threat of being eaten, a hard limit to the self's constructed autonomy. McClane, the capo from Prayers for the Stolen, is nicknamed "Cannibal" and rumored to feed "human meat" to his big cats, like Yolcaut does in Fiesta (Villalobos 34). But female bodies, in particular, are also consumed as a commodity, and this phenomenon underscores the distinct orientation of each novel toward consumption according to its gendered perspective. In contrast with the active-constructive relationship with consumption enjoyed by Tochtli and Yolcaut in Fiesta, Ladydi and the other girls and women of her community are, at best, passive spectators of consumption and, at worst, its objects. Clement, a US-born writer who grew up in Mexico, undertook a decade of research on human trafficking there and affirms that many scenes in the book, such as that of the narco party where thirty women are auctioned off in a tent, have a basis in the testimonies of women she interviewed (Wood).

In fact, Prayers for the Stolen assiduously develops a disturbing vision of female bodies as ultimately disposable commodities, born of and destined for the trash heap. This theme emerges with the introduction of Ruth, whose 
beauty parlor forms a precarious safe space within the community. Ruth "was a garbage baby... born from a black plastic garbage bag that was filled with dirty diapers, rotten orange peels, three empty beer bottles, a can of Coke, and a dead parrot wrapped in newspapers. Someone at the garbage dump heard cries coming out of the bag" (Clement 24-25). In this way, an associative link is established between female bodies and trash that is further developed through the character of Aurora, who was a sex slave of the narcos and then escaped but now languishes in jail huffing pesticide fumes, throwing herself away after having been thrown away by society. On her bed, "pushed up against the wall, were dozens of plastic supermarket bags ... Aurora's bed was a garbage dump" (190-92). Relating what it was like to be a slave of the narcos, Aurora states, "We all knew that when we gave ourselves to these men it was like washing dishes or taking out the garbage ... It was like being a urinal" (192). Sex slavery is thus cast as being a receptacle for waste products but also as labor, in a way that brutally defamiliarizes the latter, demanding a recognition that extreme economic conditions may effectively produce comparable bodily confinement and gendered exploitation. Both the extreme masculinity of the drug capos and the more "refined" rationality of economic interests commodify women as products that may be used, exchanged, or discarded as needed.

Indeed, the vision of a sex slave who is avidly bought and sold but ultimately identified with waste aligns with Melissa Wright's treatment of the maquiladora worker who paradoxically is desirable precisely because of her constructed disposability: "this internal contradiction means that this disposable third world woman is, in fact, quite valuable since she ... generates widespread prosperity through her own destruction" (2). Wright maintains that an ideology of these workers as "waste-in-the-making" is promoted by transnational corporate interests, but emboldens all perpetrators of violence against women and promotes official insouciance on the question (89). The disturbing sense of mundanity caused by Aurora's description of sex slavery crops up again when Ruth disappears, presumably kidnapped. Ladydi narrates how her friend's grandmother reacts to the news: "A missing woman is just another leaf that goes down the gutter in a rainstorm" (Clement 6I). With this statement, Ruth has completed a discursive circuit that starts and ends with refuse: discarded at birth, she is finally naturalized as a leaf in a gutter, a development that jars the sensibilities of the distant reader, while simultaneously begging the question of whether "we" are implicated, as Wright suggests, in a similar acceptance of the exploitation and disposal of female bodies as a distant, inevitable or "natural" by-product of narco-violence.

Such naturalization, of course, happens through the production and consumption of meaning, of information. Ladydi considers the mechanics of 
its transmission and reception, the layers of technological and human mediation through which it is filtered, and its effects on the receptor, in the simple but incisive terms of a perceptive child. She meditates on the rumor road that brings news of her father from the US - in a form distorted by the verbal mutations of many mouths - and on her community's dependence on Mexico's corporate telecommunications monopoly (Clement I2-I3, II9). The most important medium of information in both novels, however, may be television, whose repetitive projection of violence is part of what turns death into merely an aesthetic spectacle for Tochtli.." However, his defamiliarizing childish perspective is applied to what he sees on television as well, as when televised coverage of the discovery of "restos humanos" in plastic bags causes him to imagine grocery stores that sell human body parts (Villalobos, Fiesta 84).12 In this way, television provides raw material from the adult word to be refashioned in destabilizing ways through childhood creativity, even while its relentlessly repetitive nature imperils this very capacity. This is seen in Prayers for the Stolen, where television figures a complex intervention in the lives of the characters, and ultimately threatens to domesticate Ladydi's unconventional ways of seeing. Ladydi's mother is an avid watcher of educational television, claiming a worldliness informed by what she calls her "television knowledge" (Clement 5I-52). Ladydi picks up this concept, but she narrates her experiences with television reflexively, pointing to the way television knowledge functions as an alternative epistemic system that mediates the subject's relationship to lived experience.

When Paula asks Ladydi, "Don't you feel so sorry for Britney Spears?" she is acting on the familiarity created by television, which can be experienced like friendship or acquaintance, as in this somewhat ironic instance (73). But this sense of familiarity has other, more problematic implications, as Ladydi realizes suddenly when she goes to work in the mansion of a wealthy Acapulco family. Since the lifestyles of affluent people like them are the subject or setting of much television programming, Ladydi realizes that "I had seen their house on television" (Clement I22). It strikes her that even if she went to see the Egyptian pyramids, "they'd be familiar" (I22).

Finally, I remembered some of the violence and catastrophes I'd watched on television that had helped to build my television knowledge. When I thought of this, I tasted sour milk in my mouth like milk that sat out on the table in the jungle heat for too long. Yes, a flood could feel familiar. Yes, a car crash could feel familiar. I thought yes, a rape could feel familiar. Yes, I could be dying and even the deathbed would be familiar. (I23) 
It is notable that the two types of phenomena Ladydi notes as having been familiarized by television are excessive wealth and violence/disaster. If it is true that narrative focalization through characters like Ladydi and Tochtli functions to defamiliarize the world as perceived by adults, here we gaze into the reassuring eyes of a composite agency that would subvert this ability, domesticating the child's anarchic associative faculties by deadening her affective connections to the world. Ladydi intuits that something of value is being corrupted, suddenly tasting sour milk in her mouth. Through repetitive media representations, extreme inequality and violence lose their ability to shock, becoming naturalized to the extent that viewers undergo "a change in the structure of their experience" in which psychic defenses insulate the self from the affective jolts of extreme experiences, promoting habitual, automatic responses (Benjamin "On Some Motifs" 314, 327-29).

However, when Ladydi is later arrested for a high-profile murder and paraded before the television cameras, she makes a striking gesture affirming her own agency in the face of this technology: she "remembers" that

If I looked up, and let myself be filmed, my eyes would pierce right through the camera ... In two seconds the image of my face would be beamed down straight into the television screen and right into my two-bedroom home on our mountain ... I looked into the camera and deep into my mother's eyes and she looked back. (Clement 147)

As the familiarity between the viewer and the viewed in this instance becomes literal, we may do well to remember Raymond Williams's caution against viewing television as a "determined technology" that creates a closed, one-way system of control. Determining factors may "set limits and exert pressures, but neither wholly control nor wholly predict the outcome of complex activity within or at these limits, and under or against these pressures." (130) That is, while television may indeed act as a vector of cognitive and emotional addictions that naturalize violence and inequality and bludgeon childish creativity, it does not do so in a vacuum, but rather within an entire social constellation that includes influences originating much closer to home that may either reinforce, defy or modulate its effects. When Ladydi stares into her mother Rita's eyes through the television broadcast, the resulting mise en abyme superimposes Rita and the television as primary agents of Ladydi's socialization. To the extent that Rita embodies rigid and destructive adult habits - through her alcohol and television addictions and her obsessive thought patterns - she reinforces the interpellation undertaken by television to constitute Ladydi as a passive subject in which those patterns are reproduced. But just as Rita's adult 
rigidity threatens to infect Ladydi, Ladydi's creativity is still reflected in her mother, and their bond is an important and ultimately positive force in the novel. When Ladydi stares into the camera, Rita, like Nietzsche's abyss, stares back (Clement I47; Nietzsche 69). In what follows, we will explore the generational dynamics by which children risk becoming the "monsters" they fight.

FAMILY VALUES AND GENERATIONAL TRANSFORMATION

Though they could be called narco-novels, defining that term broadly, ${ }^{13}$ Fiesta en la madriguera and Prayers for the Stolen are also fundamentally novels about families, especially about the relationships between children and parents as the former are socialized - or domesticated - into the worlds they've been born into. This is the context of the struggle between the childhood perception that perpetually threatens to undo and remake the adult world and the replication of the addictions of self that thwart this challenge. The gender profile of the family unit in each novel could not be more different, and the differences in the dynamics and outcomes of these struggles should be analyzed in the light of these distinct models of family. On Ladydi's mountain, "family" primarily means children and a mother or grandmother but also allows for strong familial bonds between friends. For all its intimacy, though, the ability of community members to take care of each other is curtailed by adverse circumstances, as is also the case with Ladydi's mother.

Here, the process of domestication is also complicated by the fact that Rita herself is an eccentric woman whose way of perceiving life already has defamiliarizing tendencies, as in her interpretation of Paula's contamination with paraquat, the poison used in aerial drug crop eradication. One day, while the children are on their way to school the helicopter approaches, and while most of the children make it to the schoolhouse in time, Paula does not and is drenched in the poison. Her contamination is viewed as permanent, and Ladydi's mother gravely warns, "Daughter, my child, this is, of course, an omen...." (Clement 57). Ladydi concludes that "She was right. Later, when Paula was stolen, I knew this day had been an omen. She was the first to be chosen" (58).

By connecting crop spraying to Paula's kidnapping and victimization, mother and daughter's magical thinking intuits the link between gender violence and the US-Mexico drug war. Ladydi relates that "[t]hose army helicopters had to... report that they had dropped the herbicide so they dropped it anywhere they could. They did not want to get near the fields where they could get shot down for sure" (39). The conflicting demands emanating from the United States - for drugs and for interdiction - have predictably created a lucrative and dangerous industry in the midst of 
widespread poverty and desperation in Mexico. When interdiction measures confront criminal organizations empowered and enriched by demand and prohibition, feckless or collusive official agents "dump" the problem on the poor, and, increasingly, criminal actors enjoy the impunity to literally rape and pillage, as exemplified fictionally by Paula's abduction. Ladydi's "childish," magical association of crop eradication and cartel violence thus elegantly establishes a causal linkage often missed by more rational minds.

While Rita clearly retains some childlike cognitive flexibility, a truncated existence of crushing poverty as a young single parent in rural Guerrero has inculcated in her a philosophy of radical pessimism and vengeance, and her acute alcoholism has locked her into the perpetual reenactment of her abandonment by her husband and the obsessive rehearsal of a fantasized revenge. Ladydi observes, "I watched my mother cut the tall grass with her machete, or kill an iguana by breaking its head with a large stone ... and it was as if all the objects around her were my father's body" (Clement 20). Ladydi not only identifies her mother's obsessive rehearsal of vengeance but is also able to astutely connect her mother's alcoholism, her abandonment, and her association with death: when her teacher, José Rosa, comes to her house, she shows him her mother's "beer-bottle cemetery" (53). This is after a conversation in which José, who is from Mexico City, asks Ladydi's mother about the absence of men in their village. In the context of the conversation between Rita and José, the beer bottles offer a glass tombstone not only for Ladydi's father, but for every man absent from the village. Rita's creative and critical intellect and parental affection are dulled by the pressures of her environment and her alcoholic self-medication, turning her into a dangerous nihilist for whom "la vida no vale nada" (20). Her dedication to vengeance ends up perpetuating violence against the innocent when - in a drunken misidentification - she shoots Maria, her husband's illegitimate daughter (89-90). She bounces back and forth, in a violent oscillation between her defamiliarizing tendencies and rigid, addictive patterns of thought and behavior. When Ladydi asks Rita why she drank herself unconscious during José Rosa's visit to their home, Rita explains, agitated: "I was just turning inside out, turning inside out so that my bones were on the outside and my heart was hanging here in the middle of my chest like a medallion. ... I knew that man could see my liver and my spleen" (54).

In the context of ubiquitous male violence, even Ladydi's teacher's relatively benign inquiries are experienced as threatening incursions into the female self. Ladydi also retains this ability to see inside bodies, but she is better able to integrate these visions into her life. She dreams about Julio, the gardener with whom she had a romantic affair while living in the 
Acapulco mansion. In the dream, "I could see inside of his body. Under his flesh I saw the stars and the moon and I knew he was born from space" (Clement 196). The idea of girls and women turned inside out reaffirms their perpetual endangerment in contemporary Mexico; the palpable, gendered vulnerability of Rita's image is worthy of Frida Kahlo. ${ }^{14}$ The cosmic image of Julio, on the other hand, suggests a certain freedom and expansiveness underwritten by the privilege of a maleness that to some extent shields him from harm. But in both cases the boundaries between the outside and the inside of the human body have been sundered, the interior coming into contact or even identity with the exterior. The selves Ladydi describes are quite far from the isolated, "egotistical, almost solipsistic" bourgeois idea of self that Benjamin sought to shatter (Gardiner 19), instead casting the human body as a dialectical image that exposes its dual nature as "natural creature and class subject" (Bolz and Reijen 56). The destabilization of the inside-outside boundary means that fear and other intoxicants are not foreign contaminants but rather members of social and biological economies that link, motivate, and constrain bodies. ${ }^{15}$ The destruction of adult, narcossist subjectivity leaves space for the animal body that suffers and perceives and for the collective political body that is the object of illuminated vision and the agent of collective action. Family, as the received context that familiarizes and narcotizes, gives way to the possibility of bonds of kinship, congenital or otherwise, that are forged in the consciousness of shared vulnerability.

Fiesta en la madriguera, on the other hand, is characterized by a lack of women in the family context. Consequently, the meaning of family in this text is drastically altered: the biological family unit constituted by Yolcaut and Tochtli is reconceived as a pandilla, and its values are established on this basis. Foremost among them is "ser muy macho" and the closely related negative value of "no ser marica." 16 The status of macho is tightly linked in the novel with the idea of being "El rey," informed here by the José Alfredo Jiménez classic. The song emphasizes the irrelevance of material wealth or comfort, pronouncing that even without them, "sigo siendo el rey" (Villalobos, Fiesta 28). Tochtli understandably does not seem to comprehend this completely: "Lo mejor de ser rey es que no tienes que trabajar" (29), but he does astutely note that the ultimate arbiter of kingliness in the song is the fact that "mi palabra es la ley." Thus, el rey is someone who continues to exercise power even in the face of material privations, projecting a radical autonomy (sovereignty) that rejects the mutual need for cooperation ("Hago lo que quiero") and human connection ("No tengo trono ni reina / Ni nadie que me comprenda") (28-29).

Unlike Jiménez, Tochtli places a great importance on the material appurtenances of royalty; as a connoisseur of headwear, the crown is of 
special interest. For him, "Sólo tienes que ponerte la corona y ya está, las personas de tu reinado te dan dinero, millones" (Villalobos, Fiesta 29). What is striking is that, for all the desirability of being king and having a crown, the novel's cranial motif extends to Tochtli's great appreciation for guillotines and the work they do. Considering Yolcaut's association with kingliness, Tochtli already seems to understand and accept the short but intense life-cycle of the successful drug trafficker.17 He appreciates the French in part because "le quitan la corona a los reyes antes de cortarles la cabeza" (24). They also take care with the head itself, placing it in a basket so that "no se les escape rodando" (42).

This apparent ambiguity may be related to the peculiar social position Yolcaut - and every powerful capo - occupies. On one hand, they exercise a sovereign power over life and death within their considerable spheres of influence, causing frequent portrayals of these figures as monarchs. However, their (apparent) exteriority to the state and the rule of law place them in an ultimately precarious zone of exception. ${ }^{8}$ When their regime of what Rosanna Reguillo calls "paralegalidad" fails (44), narco-executives like the people further down the chain of command in their organizations find themselves subject to being killed without legal repercussion. Thus, the "symmetrical figures" of the sovereign and the homo sacer (Agamben 84) overlap in the person of the narco-rey, leading Tochtli to identify with both the beheader and the beheaded. ${ }^{9}$ Ultimately, then, the sovereign autonomy and power over others of the rey and the macho is as precarious as the narcossist's brittle sense of superiority.

This vital precarity also links el rey with his victims, whose fate is figured in a macabre reverie that joins the motifs of decapitation and cannibalism; as Tochtli muses, "Yo creo que si vendieran cabezas cortadas en el súper las personas las usarían para hacer el pozole" (Villalobos, Fiesta 84). Here the heads are placed within the banal, commercial context of the grocery store, where they become simply another commodity for sale, juxtaposing the violence of the narcotics industry with above-board economic practices. Placed alongside animal bodies for routine consumption, human beings are reduced to zoe in the eyes of both the cartels and the state, ${ }^{20}$ the zone of exception expanding to include nearly anyone suffering a violent death in Mexico, often automatically considered to have been involved in criminal activity and thus outside of the serious consideration of the law (Watt and Zepeda i85). The narco-pozole represents a desacralization of Aztec ritualistic anthropophagy, the public sacrifice privatized into consumption of bare life for profit (López-Badano 69-70). But Tochtli's cannibalistic fantasy is also rooted in the fact that everything he consumes is paid for with blood money. This is an insight that threatens to infect anyone whose own sense of self is permeable enough to 
recognize that many or all of us - whether we are buying cocaine, consumer goods or simply paying taxes that go to the Drug War - are in a sense purchasing and eating that same human head pozole. Far from being closed, autonomous beings, we incorporate the blood and sweat of others, and experience psychotropic effects like the dopamine rush of cocaine or shopping, a rush of righteousness or a debilitating guilt, depending on how we feel about drug interdiction efforts.

For all his intuitive defamiliarization of machismo, it is a part of the pandilla's ethic that Tochtli tries to fully accept and internalize, attempting to mold himself in Yolcaut's image. In other areas of the ideology into which he is being initiated, he finds that Yolcaut's behavior often falls short. Most importantly, "las pandillas se tratan de ... no ocultarse las verdades" (Villalobos, Fiesta 46). Tochtli suffers severe disillusion with Yolcaut's leadership when he finds out that the latter had hidden from him the fact that they keep stores of weapons and ammunition in certain spare rooms of the palace. This precipitates the crisis that threatens to see Tochtli pull away from his father definitively. As a move in this direction, he imaginatively embodies the principles Yolcaut has betrayed by turning himself into a samurai. His internalization of the security culture imposed by his father plays into his own ideas and imaginations about samurai culture, and he becomes fixated upon maintaining a stoic and honorable silence: "Ahora me llamo Usagi y soy un mudo japonés" (49). In this way, he withdraws yet further into himself, intensifying the effective imprisonment he has suffered due to the extreme security measures called for by Yolcaut's business. This is the cost and correlate of the extreme privatization that narco-culture borrows from neoliberal capitalism and intensifies. Novelist Juan Villoro has noted that "el narco depende de eliminar el afuera y asimilar todo a su vida privada: comprar el fraccionamiento entero, el country, el estadio de fútbol, la delegación de policía," and that in this "burbuja ... no hay que fingir ni que ocultarse porque los espectadores ya han sido comprados" (35-36). This expansion of the self nevertheless continues to be counterposed to an exteriority with which it becomes increasingly hostile, any incursion being a threat capable of bursting the "bubble." In this sense, the pattern also mirrors the comportment of the heavy cocaine addict, who physically walls himself off in his bedroom as long as his supply holds out, and in general that of the narcossist, who psychically wards off the Other to defend the overinflated bubble of self.

In this way, even though Tochtli is attempting to take a stand against an adult hypocrisy that says one thing and does another, that hides the truth at the expense of the childlike propensity and desire to "ver las verdades" (Villalobos, Fiesta 72), his process of withdrawal in fact forms a stage in his training and his passage to narcossist adulthood under the guidance of his 
father. He must transform from a coddled "conejito" safe in his "madriguera" into an emotionally withdrawn young man capable of venturing out into the world to take over Yolcaut's business, with all the violence it entails. The strain of the transformation is evident: after Tochtli discovers the arsenal room and absconds with a small pistol, he seems to teeter on the border between infant and man, as scatology blurs with the munition in his internal discourse: "Los conejos hacemos caca en bolitas. Unas bolitas perfectas y redondas, como las municiones de las pistolas. Con las pistolas los conejos tiramos balas de caquita" (50). Here the identification with a small animal figures childhood as weakness, as potential victim, whereas the adoption of violence and aggression portrays adulthood as humanity, or at least a more dominant animality. Silence and self-containment finally lead to the suppression of childish exuberance and the psychotropic construction of a closed self, as well as the stealth of a predator; after all, "a las pistolas puedes ponerles un silenciador, que es para convertirlas en mudas" (IO2).

The transformation reaches its final phase as the result of the traumatic event that occurs near the end of the novel. Childhood perception, an intoxicated state from the adult perspective, may allow one to see otherwise hidden truths, but seeing the truth of violence may also have a profound domesticating effect, as Tochtli finds out when he witnesses the death of his beloved Liberian pygmy hippopotami. Before reaching this state, however, he first purges his vulnerability and grief. In a line as sad as the rest of the novel is funny, Tochtli notes his reaction to witnessing the euthanasia, by multiple gunshot, of his new pets: "Entonces resultó que no soy un macho y me puse a llorar como un marica" (Villalobos, Fiesta 75). Here, though Tochtli's matter-of-fact tone does not waver. The harshness of his selfindictment, in the face of his failure to comply with impossible and damaging norms, marks an ephemeral pause in the relentless narrative irony, during which the reader is invited to feel compassion for this fictional child. His sadness soon turns into an apocalyptic rage, however, (and Villalobos's intransigent black humor prevents pure pathos from taking over), as he wishes "que me dieran ocho balazos en la próstata para hacerme cadáver" and "que todo el mundo se fuera a la extinción" (75).

Here, Tochtli has no choice but to abandon the intoxication of machismo (of power, of autonomy), giving in to the debilitating intoxication of grief. But on returning to his life in Mexico there is no support system to facilitate a permanent way out of machismo, so he retreats into his samurai alter-ego, which preserves the received values of masculinity (Villalobos, Fiesta 7980 ). He thus reconfigures the pandilla's code of ethics into a private and imaginary samurai world that excludes his father. We observe him beginning to reproduce Yolcaut's secrecy, as when he gives Mitzli, his friend and Yolcaut's guard, a list of things he wants, including a "samurai" saber - 
a list that is not to be shared with his father. Here he is progressing from a faithful adherence to the supposed norms of the pandilla toward the adoption of adult hypocrisy.

When Yolcaut takes him to see the room where they keep their store of weapons, this gesture opens the way toward a reconciliation (Villalobos, Fiesta I02). However, the definitive moment comes with Yolcaut's gift to Tochtli of the desiccated heads of the hippos. It is at this point that he refers to Yolcaut as "mi papá" for the first time (IO4), signaling that he has been definitively brought into the fold. Tochtli had explicitly rejected the idea of killing these animals for trophies as he knew was common practice (57), instead seeking them for the companionship for which he was starved, but the regal, if ill-fated, names he chooses for them, Luis XVI and María Antonieta de Austria (73-75), tip the reader off that disaster is imminent. When his grandiose yet innocent plan to have these animals as pets runs up against external factors, however, instead of having to face failure and continue his psychic development according to the reality principle, Yolcaut offers him an alternative. The stuffed heads show Tochtli the superiority of satisfying desire through domination, death, and consumption; the closure and fortification of the self and the reduction of the Other to a decorative head on the wall. Tochtli's upbringing had long inclined him to equate values like solidaridad with giving and receiving gifts (13), and with this final coup, Yolcaut seals Tochtli's initiation into the world of adult hypocrisy, as he accepts bribes to compensate for broken promises and compromised principles. He abandons his autonomous samurai world and dress and his defiant silence, once again bought into compliance. Yolcaut makes a conciliatory gesture toward Tochtli's demand for integrity by showing him the arsenal and delivering the child's long-desired hippos, but Tochtli must accept his dreams disfigured, decapitated. A simulacrum of happiness, childhood, and life, and a mockery: the heads are made to wear the hats of the safari that brought their death, and then the crowns that brought their namesakes' beheading. Similarly, Tochtli's wealth is a poor compensation for a life that will be ruled by paranoia, fear, the psychic damage of violence, and a paralyzing standard of masculinity. Tochtli's desire for companionship is thwarted and he must accept possession through violence, the companionship of death.

In conclusion, Prayers for the Stolen and Fiesta en la madriguera represent complementary visions of the psychic struggles implicit in socialization in the troubled days of the Drug War. The young narrators, living up to Benjamin's appreciation of children, construct new visions out of the detritus of the adult world, intoxicating the narcossist notion of a closed, autonomous self that characterizes consumerism and purity discourses about drugs and violence. Clement's novel is about survival and 
survivors, both in physical terms and with respect to the preservation of that childlike cognitive and emotive flexibility which can still blossom among the forgotten, and upon which all hope depends when adult norms seem to veer towards apocalyptic outcomes. In a sense, Ladydi stands in for young people around the world who find themselves under the wheel of an economic system that promotes a broadly conceived "privatization" with increasing aggression, so that more and more individuals find themselves victimized, or forgotten and irrelevant. Villalobos, on the other hand, brings us an "(Anti)Bildungsroman," where we witness "la deformación de la formación" of Tochtli as he undergoes the painful transition from wildly creative child to cold-blooded practitioner of "capitalismo gore" (López Badano, Valencia). Despite this eventual identity, the compassion for Tochtli evoked in moments like the death of his hippos is a reminder of his originary victimhood and connects to a larger group of children, namely those born into a privilege that they did not ask for, but whose price they pay with their isolation and the psychic damage associated with a system of values that revolves around status and consumption.

Ladydi's vital resourcefulness is related to her appreciation of the precariousness of the boundaries between inside and outside, good and evil, even life and death. In Prayers, the Virgin of Guadalupe is transformed into the Virgin of the Sea, who is not only "el consuelo de los pobres ... el amparo de los oprimidos" (Paz 77), but actually participates in the people's defeat. "[D]rowning under the waves" (Clement I43), she experiences the sense of danger and desperation felt in contemporary Mexico; "[b]ottle green" and immobile (135), she is already a corpse. Aurora and others are characterized as drowned people still walking the earth, their lives having been capsized by violence and powerlessness. The resulting deathly selves, however, never lose their agency. ${ }^{2 \mathrm{II}}$ In jail, Ladydi marvels that women who had been victims and perpetrators of extreme violence were capable of "[s]mall acts of kindness [that] could turn me inside out ... My skin was on the inside and all my veins and bones were on the outside" (156), astutely pointing to the connection between the shared vulnerability discussed above and a necessity for solidarity.22 She is, in effect, engaging in Benjaminian "ragpicking" among the human detritus of contemporary Mexican society, attempting to "glean what is worthwhile out of what has been discarded or forgotten," and indeed finding "signs of utopian possibility within marginalized or suppressed human experiences" (Gardiner 2I).

The solidarity of the drowned is powerful because the further an object, person, or experience is from the main flows of phantasmagorical commodity culture, the more likely it, or she, may be able to throw a stark, defamiliarizing illumination on the images that support its ideologies. When Ladydi learns that Aurora knew Paula when they were held by the narcos, 
Aurora tells Ladydi's story as she learned it from Paula, and Ladydi notes, "My life had suddenly turned into a wishbone. Aurora had brought the pieces together. She was the joint" (Clement I83). As Aurora tells their jail community the story of Ladydi's life, "I looked at Aurora and thought I was looking into a mirror. She knew my life better than I did" (I84). Ladydi's age, gender, and marginal position mean that she has not completely assimilated the ideology of the discrete and autonomous self, and instead her cognitive creativity leads her to "the intuition of a subject that, at each point in the present, remains unfinished and open to a becoming of the other that is neither simply passive nor simply active" (Irigaray 95). Through Aurora, Ladydi's self is supplemented through an external, constructive gaze that can only be supplied by the Other in a process of co-creation. In this way, Ladydi's idiosyncratic elaboration of the world enables us to glean from the jail's human wreckage a vision that defamiliarizes the self by incorporating the gaze of the Other, simultaneously consummating the inner world with a view from outside and thus constructing a jointed, multiple self, capable of observing itself from any angle. Such selves, deindividuated and injected with the radical otherness of death, destabilize the closed, unitary subject that supports the sovereign self-as-consumer of the global economy as well as the pure and impermeable collective self of Drug War ideology, rejecting narcossism in favor of utopian glimpses of a community forged in pain and shared vulnerability.

Fiesta en la madriguera, on the other hand, underneath the breezy hilarity of Tochtli's tale, offers an essentially pessimistic view of the suppression of childhood perception's utopian possibilities, in the service of the reproduction of a radical narcossism. This narcossism is supported by the maintenance of rigid boundaries that Tochtli applies in strict but characteristically bizarre ways. While Tochtli is accustomed to murder and dismemberment, human hair really gets under his skin: after all, "El pelo es una parte muerta del cuerpo ... que crece y crece sin parar" (Villalobos, Fiesta 43). It would be a mistake to discount Villalobos's black sense of humor here, but it is also worth noting that while consistent exposure to violent death has lead Tochtli to accept the abrupt cancellation of someone's very personhood at any time, the specter of death within life, ever encroaching on subjectivity, is intolerable to him. ${ }^{23}$ Tochtli has already assimilated a psychic strategy that supports his developing performance of masculinity by denying personhood to the dead and denying the presence of death or weakness within himself. The constant threat of death is manageable as long as the dead are not seen as persons who have suffered and are deserving of compassion and mourning. When the pain and loss of death manifest in the living person, as in the proliferation of nonliving hair cells, it becomes an abject threat to the system of self that must be shunned, 
as it opens the self to the pain and weakness that is, of course, part of that self, but that is inadmissible according to the standards of the constructed masculinity at play.24 This dynamic of abjection will continue to serve Tochtli as a psychotropic technology in service of maintaining a rigid, narcossist self that builds itself up through radical social and ethical isolation. It is a very "adult" operation, but the eccentric way in which it manifests signals Villalobos's keen and humorous appropriation of the defamiliarizing optics of childhood. ${ }^{25}$

Such a vision gives us a glimpse of the "child's side" of our era - to return to this article's epigraph - in which the unconscious structure of a now global society comes into view: a mass-produced narcossist subjectivity that undergirds the adult "consensus that comprises the tyrannical realm of fact" (Jenks 25). Children's perspectives are shunned by adults because these challenging, chaotic, "childish" epistemologies intoxicate this oppressive consensus, showing a potential to radically remake the world by reconfiguring "waste products ... of widely differing kinds in a new, intuitive relationship" (Benjamin, One-Way Street 3I). Fiesta en la madriguera and Prayers for the Stolen also show how violence and narcossism reproduce themselves at all levels through the suppression of this creativity and the atomization of experience, but the protagonists' disorienting point of view is contagious, and their intoxicating perspective destabilizes the cognitiveemotional addictions of self that uphold elements of global Drug War discourse like the purity of the Northern social body, made up of closed, autonomous selves, to be protected against contamination by drugs from the South; the radical Otherness of the drug trafficker as opposed to the clean and proper, licit consumer; and the a priori guilt of all of those killed in the Mexican guerra contra el narcotráfico. Moving beyond these rigid and simplistic patterns of thought allows for a mental shift by which psychotropy may be examined as a multivalent but fundamental human phenomenon, and its causes and effects may be evaluated in the context of global linkages and patterns of intoxication. The self would no longer be defended as a closed system that is vulnerable to contamination be the Other; rather, such atomization would itself be viewed as a destructive form of intoxication that perpetuates violence and coincides with patterns of drug abuse. The selves created in this way, in turn, could be seen as units of a cultural system that functions in support the global economy, with all that implies.

Augustana University 
NOTES

I For psychologists Martha Koukkou and Dietrich Lehman, "the interpretation of the internal and the external realities of the young child during sleep is not so different from the interpretation of the realities during wakefulness" (95).

2 Compare William Burroughs's assessment of the effects of LSD: "LSD lets you do something you would be able to do anyway if you hadn't been conditioned not to" (I22).

3 The term "narcossism" originates with Avital Ronell (Crack Wars 23). I use the term here to describe addictive patterns of psychotropy that inflate the ego in the manner of pathological narcissism (APA). I define "intoxication" very broadly, in order to include both substances and cultural practices that demonstrably change the way beings think, feel, or perceive. I use "psychotropy," a term introduced by historian Daniel Smail, as a synonym of intoxication. Paralleling the ambivalence of the pharmakon as both poison and cure, intoxication can refer both to dynamics of narcossism and to the disorienting effect of childish perspectives or similar aesthetic experiences. This last usage is in line with the etymology of "toxic": from Greek, toxikon, a poisoned arrow that penetrates the self to introduce something Other. See also Mel Chen's theorization of toxicity and the erasure of ontological boundaries, of "an intimacy that does not differentiate" (203). Toxicity, like queerness, "truck[s] with negativity, marginality, and subject-object confusions" (207).

4 Susan Buck-Morss theorizes this Western self in her magisterial essay, "Aesthetics and Anaesthetics: Walter Benjamin's Artwork Essay Reconsidered."

5 Also see Harston on compulsive shopping disorder.

6 For more on narcossism, consumerism, and the intoxication of the "drug warrior" - as well as a general consideration of the importance of psychotropy in the analysis of narconarratives - see Patteson.

7 Jordan Belfort is a former stock broker who was immortalized in the Martin Scorsese film The Wolf of Wall Street, in which his character's extreme lifestyle of drug use, sexual rapacity, self-aggrandizement, and cynical utilization of other people makes him a paragon of the narcossist mode of self.

8 Felipe Oliver Fuentes Kraffczyk maintains that the "la transformación o incluso la destrucción del cuerpo," in Fiesta and other texts, parallels the dissolution of the social body, part of a "derrumbe moral" leading to a "sociedad en franca destrucción" (2I-22). While this may be true, their visions of the body are too rich and disturbing to leave it at that.

9 Tochtli comments on Mazatzin's case: “Cobraba millones de pesos por inventar comerciales de champú y de refrescos. Pero Mazatzin estaba todo el tiempo triste, porque en realidad había estudiado para ser escritor. Aquí 
comienza lo sórdido: que alguien gane millones de pesos y esté triste por no ser escritor" (Villalobos 15-16).

IO This interpretation is supported in Granta's interview with Villalobos.

II Adriaensen notes the similarities between Tochtli's callousness and that of the young narrator of Cartucho, Nellie Campobello's classic, episodic account of the Mexican Revolution ("La violencia" 35).

I2 This will be discussed further in the next section.

I3 It is worth noting that Villalobos has stated a strong opposition to the notion of narcoliterature, or at least to his work being identified as such (Adriaensen, "El exotismo" 159).

I4 In the words of Hayden Herrera, Kahlo tried "to find wholeness by painting self-portraits in which she turns her body inside out ..." (38).

I5 Smail develops this concept, coining the term "psychotropic economy" (I6I).

I6 According to Edith Beltrán, in this context "El ser machos" consists of being "estoicos, sin necesidades, con gran potencia sexual proyectada que legitima su poder de hacer leyes que les convengan y donde todos y todas están bajo su dominio" (I28).

I7 Jungwon Park and Gerardo Gómez-Michel write of "la lógica de gasto económico y humano que acentúa la tragedia inherente al 'oficio' del narco: vida intensa, derroche y muerte prematura."

I8 Jungwon Park and Gerardo Gómez-Michel note, with reference to Giorgio Agamben's notion of homo sacer, that "la vida humana es sujeta a ser aniquilada sin ser considerado este acto como 'homicidio' ... justo ahí donde se ha decretado la excepcionalidad (83), como es el caso del espacio social (y legal) ocupado actualmente por la industria del narco, al que se declara enemigo de la soberanía nacional."

I9 Fuentes Kraffcyz, analyzing Tochtli's obsession with decapitation, astutely notes that "parece más interesado en el poder que en la violencia per se," but for Fuentes Kraffczyk, this violence constitutes a reconfiguration of society by the cartels, an effort to "intervenir el estado hasta desarticularlo" (3I). I would argue that it rather represents the precarious state of affairs left by a state already disarticulated by national and transnational neoliberal policies, a situation exacerbated by militarized drug prohibition.

20 See Tarica's discussion of this idea, which the poet Javier Sicilia and others adapt from Agamben.

2I Julio claims to be a drowned man, having escaped after killing a border guard and disappearing into the Río Grande (Clement 133-34). Aurora, especially, is characterized in the narration through a well-developed association with the ocean and death: a "small fish" when she was first kidnapped at twelve years old (193), her discolored skin is rough as if sandy (195). Her eyes remind Ladydi of "dead jellyfish" (193), but also of "the glass in a glass-bottom boat" (194). Regarding the agency of the drowned Aurora, for instance, relates how she 
performed an act of resistance by killing five of her captors and their associates (I94). Thus, the "drowned" as discussed here should be contrasted with the more radical conception of Primo Levi, for whom the "drowned" Holocaust survivor "no longer had room in his consciousness for the contrasts good or bad" (83-84).

22 This pattern to some extent mirrors what Estelle Tarica calls "countervictimization."

23 It should be noted that, in addition to his habit of keeping his head shaved (Villalobos, Fiesta 43), and numerous protestations about bad haircuts and the like, in his cannibalistic pozole reverie, Tochtli specifies that the hair must be pulled out of the human heads (84). He is also repulsed by the teeth of the pig's head simmering in a real pozole, teeth being, like hair, composed largely of dead cells (20).

24 On the abject threat to the system of self, see Kristeva (4). Tochtli's aversion to hair could also connect to the experience of horror itself. The Latin roots of the word "horror" refer to "the bristling of the hair on one's head" (Cavarero 7). Shunning hair could constitute a psychic defense against the experience of horror itself, which is forbidden to Tochtli by the codes of masculinity.

25 See Adriaensen on the ethics of black humor in the context of Fiesta en la madriguera and of narco violence in general ("El exotismo" 157-59).

\section{WORKS CITED}

ADRIAENSEN, BRI GIT TE. "El exotismo de la violencia ironizado: Fiesta en la madriguera de Juan Pablo Villalobos." Narrativas del crimen en América Latina: transformaciones y transculturaciones del policial. Eds. Brigitte Adriaensen and Valeria Grinberg Pla. Münster: LIT Verlag, 2012. 155-67.

—. "La violencia desde la perspectiva infantil: una lectura comparativa de Cartucho de Nellie Campobello y Fiesta en la madriguera de Juan Pablo Villalobos." Confluencia 32.2 (2017): 29-38.

A G A M B E N, G I R gi o. Homo Sacer: Sovereign Power and Bare Life. Stanford: Stanford UP, 1998.

American pSychiatric association (apa). "Personality Disorders." Diagnostic and Statistical Manual of Mental Disorders: Fifth Edition. Washington, D.C.: American Psychiatric Association, 2013. Web.

B E L RÁ N, MínEHAN E. P. “Gestión del 'ciudadano' y 'nación' en narcoarchivos de México en la primera década del siglo XXI." Dissertation, U of WisconsinMadison, 2015.

B En Ja min, walter. On Hashish. Ed. Howard Eiland. Cambridge: Belknap P, 2006.

—. "On Some Motifs in Baudelaire." Walter Benjamin: Selected Writings. vol. 4, 1938I94O. Eds. Edmund Jephcott, Howard Eiland, and Michael Jennings. Cambridge: Belknap P, 2003. 
—. One-way Street. Ed. Michael W. Jennings. Trans. Edmund Jephcott. Cambridge:

Belknap P, 2016.

Bolz, NoRbert W., And Willem Reijen. Walter Benjamin. Atlantic Highlands:

Humanities P, 1996.

BO RGES, JO RGE LUIS. "El idioma analítico de John Wilkins." Otras inquisiciones.

Buenos Aires: Emecé, 1960.

BUCK-M ORSS, SUSAN. "Aesthetics and Anaesthetics: Walter Benjamin's Artwork

Essay Reconsidered." October 62 (1992): 3-4I.

-. The Dialectics of Seeing: Walter Benjamin and the Arcades Project. Cambridge: MIT P, 1989 .

B U R R U G H S, W IL Li A M S. Burroughs Live: The Collected Interviews of William S.

Burroughs I960-I997. Ed. Sylvère Lotringer. Los Angeles: Semiotext(e), 200 I.

CA V A R E R O, A R R A A. Horrorism: Naming Contemporary Violence. New York:

Columbia UP, 2008.

CH E N, M E L. Animacies: Biopolitics, Racial Mattering, and Queer Affect. Durham: Duke

$\mathrm{UP}, 2 \mathrm{OI} 2$.

C L E m E T, JE N N F E R. Prayers for the Stolen: A Novel. London: Hogarth P, 2014.

ERK, SUSANNE, ET AL. "Cultural Objects Modulate Reward Circuitry." Neuroreport

I3.I8 (2002): 2499-503.

FER Mín, DANiE L. "El realismo elástico de Juan Pablo Villalobos." Zenda I3 abril 2017.

N. pag. Web

FUENTES KRAF FC ZYK, FE LIPE. Apuntes para una poética de la narcoliteratura.

Guanajuato: U de Guanajuato, 20I3.

GARDINER, MICHAEL E. "Marxism and the Convergence of Utopia and the

Everyday." History of the Human Sciences i9.3 (2006): I-32.

HARTSTON, HEIDi. "The Case for Compulsive Shopping as an Addiction." Journal of

Psychoactive Drugs 44.I (2012): 64-67.

H E R L In G H A U S, H E R M A N . Narcoepics: A Global Aesthetics of Sobriety. New York:

Bloomsbury, 2013.

her RE RA, hay D n. Frida. A Biography of Frida Kahlo. Harper Collins, I983.

I R I G A RA Y, L u CE. An Ethics of Sexual Difference. Trans. Carolyn Burke and Gillian

Gill. London: Continuum, 2004.

J I Ḿ́ NE Z, Jo SÉ A LF RE Do. Lyrics to "El rey." Genius, 20I9. Web.

JENKS, CHRIS. Childhood. London: Routledge, 2014.

KNAF 0, DAN IELlE. "Revisiting Ernst Kris's Concept of Regression in the Service of the Ego in Art." Psychoanalytic Psychology: The Official Journal of the Division of Psychoanalysis, American Psychological Association, Division 39 I9 (2002): $24-49$.

—. "The Senses Grow Skilled in their Craving: Thoughts on Creativity and Addiction." Psychoanalytic Review 95.4 (2008): 57I-95.

KoukкоU, martha, And Dietrich Lehmann. "A Model of Dreaming and Its Functional Significance: The State-Shift Hypothesis.” The Functions of 
Dreaming. Eds. Alan Moffitt, Milton Kramer, and Robert Hoffmann. Albany: SUNY P, I993.

K RIST EVA, JU LIA. Powers of Horror: An Essay on Abjection. New York: Columbia UP, I982.

LEVI, PRI M 0. The Drowned and the Saved. Trans. Raymond Rosenthal. New York: Summit, 1988.

Ló P E Z B AD AN O, C E C I l i A. "Narcotráfico y Bildungsroman: Fiesta en la madriguera, de Juan Pablo Villalobos.” Periferias de la narcocracia. Ed. Cecilia López Badano. Buenos Aires: Corregidor, 2015.

Nietzsche, Friedrich. Beyond Good and Evil: Prelude to a Philosophy of the Future. Eds. Rolf-Peter Horstmann and Judith Norman. Trans. Judith Norman. Cambridge: Cambridge UP, 2002.

PARK, JUNGWON, AND GERARDO GÓMEZ-MICHEL. "Noción de gasto y estética de precariedad en las representaciones literarias del narcotráfico." E-misférica 8.2 (2OIO): N. pag. Web.

PA t t es o n, J o S E P. "High Crimes: Élmer Mendoza's 'Zurdo' Mendieta Series and the Psychotropic Economy." A Contracorriente, I4.3 (2017): 220-47. Web.

PAZ, o C T A V I o. El laberinto de la soledad. México: Fondo de Cultura Económica, I959. REGUILLO, R OSSANA. "De las violencias: caligrafía y gramática del horror." Desacatos 40 (2012): 33-46. Web.

R O E L L, AVITAL. "Avital Ronell Interview.” Interview by Alexander Laurence. altx.com, 1994. N. pag. Web.

—. Crack Wars: Literature, Addiction, Mania. Lincoln: U of Nebraska P, 1992.

S MAIL, DAN IE L L RD. On Deep History and the Brain. Berkeley: U of California P, 2008.

SPotTs, JAmes, And FRAnklin Shontz. "Drug-induced Ego States: I. Cocaine: Phenomenology and Implications." International Journal of the Addictions $\mathbf{1 9 . 2}$ (I984): II9-5I.

TAR I CA, E ST E lle. "Victims and Counter-Victims in Contemporary Mexico." Política Común 7 (2015). Web.

VA LE N CIA, SA YA K. Capitalismo Gore. Barcelona: Melusina, 20 IO.

villalob os, JuAn pablo. Fiesta en La madriguera. Barcelona: Anagrama, 20 Io.

—. Interview with Rosalind Harvey. "Juan Pablo Villalobos." Granta: The

Magazine of New Writing 27 (20II). Web.

VI L L R O, JUA N . "La alfombra roja: comunicación y narcoterrorismo en México."

Senderos de violencia: Latinoamérica y sus narrativas armadas. Ed. Oswaldo Estrada. Valencia: Albatros, 2015.

wat t, Peter, and roberto zepeda. Drug War Mexico: Politics, Neoliberalism and Violence in the New Narcoeconomy. London: Zed Books, $20 \mathrm{I} 2$.

Wi Li iams, RA Y M O D. Television: Technology and Cultural Form. London: Routledge, 2005. 
w o o D, G A B y. "Jennifer Clement: 'I Always Have Believed That Literature Can Change the World."' The Telegraph Io Feb 20I4. Web.

W R I GH T, M E LISSA w. Disposable Women and Other Myths of Global Capitalism. London: Routledge, 2006. 